\title{
Custom as a Source Under Article 2I of the Rome Statute
}

\author{
Amit KUMAR* \\ Rajiv Gandhi School of Intellectual Property Law (IIT Kharagpur), India \\ email: amit3821ph@gmail.com; amit3821ph@iitkgp.ac.in
}

(Received 26 November 2020; revised 17 February 2021; accepted 22 February 2021;

first published online 24 August 2021)

\begin{abstract}
The adoption of the Rome Statute is a significant moment for international criminal law. Before its formulation, the criminal law was governed by the sources mentioned in their statute or Article 38 of the Statute of the International Court of Justice [ICJ Statute]. Custom is one of the important sources within the ICJ Statute. The ad hoc tribunals applied custom and even formulated certain customs. The formulation of custom is considered as against the principle of legality. To avoid such criticism, the State Parties inserted Article 21 in the Rome Statute. The provision clarifies the law which the court can apply. The parties chose not to include custom explicitly. However, the wordings of the provision indicate that the custom is still a source for the court. Apart from the wording of Article 21, other provisions of the Statute give ample scope for the application of custom.
\end{abstract}

Keywords: hierarchy, sources; custom; Rome Statute; Article 21

International criminal tribunals are primarily governed by the statutes through which they came into existence. Similarly, the International Criminal Court [ICC] came into existence through the Rome Statute and is governed by it and other instruments adopted along with the Statute. ${ }^{1}$ Before the Rome Statute, the tribunals relied upon the sources listed in Article 38 of the ICJ Statute. ${ }^{2}$ The tribunals established post World War II relied on custom as a source for fixing criminal liability. ${ }^{3}$ Custom is considered a source for

\footnotetext{
* Research Scholar at Rajiv Gandhi School of Intellectual Property Law, IIT Kharagpur, India. The paper is part of a LLM dissertation submitted at South Asian University, New Delhi. The author is grateful to Dr Srinivas Burra, supervisor, for his guidance and observations on the dissertation. The author would like to thank the anonymous reviewer for their insightful observations. The author would also like to thank Santosh Anand, Tanaya Thakur, and Aditya Roy for their support and observations at different stages of writing the dissertation and finalizing the paper.

${ }^{1}$ The other instruments include elements of crime and rules of procedure and evidence.

${ }^{2}$ See The Prosecutor v. Drazen Erdemović, Decision of 7 October 1997, Appeals Chamber, Joint Separate Opinion of Judge McDonald and Judge Vohrah, Case No. IT-96-22-A at para. 40; Mary FAN, "Custom, General Principles and the Great Architect Cassese" (2012) 10 Journal of International Criminal Justice 1063; Gideon BOAS, James L. BISCHOFF, and Natalie L. REID, International Criminal Law Practitioner Library, vol. II: Elements of Crime under International Law (Cambridge: Cambridge University Press, 2008); Theodor MERON, "Revival of Customary Humanitarian Law" (2005) 99 Asian Journal of International Law 817.

${ }^{3}$ Meron, ibid., at 817; Dapo AKANDE, "Sources of International Criminal Law" in Antonio CASSESE, ed., The Oxford Companion to International Criminal Justice (Oxford: Oxford University Press, 2009), 41 at 49; Fausto

(C) The Author(s), 2021. Published by Cambridge University Press. This is an Open Access article, distributed under the terms of the Creative Commons Attribution licence (https://creativecommons.org/licenses/by/4.0/), which permits unrestricted re-use, distribution, and reproduction in any medium, provided the original work is properly cited.
} 
these tribunals because the tribunals' statutes have made an explicit reference to "the laws or customs of war". ${ }^{4}$ In the case of the International Criminal Tribunal for the former Yugoslavia [ICTY], the United Nations Secretary-General decreed that the Tribunal should apply only those rules which had become beyond any doubt part of customary law. ${ }^{5}$ In the case of the International Criminal Tribunal for Rwanda [ICTR], since their subject matter was not limited to those crimes that have become part of customary international law only, they applied custom and treaty, which were binding upon Rwanda when crimes were committed. ${ }^{6}$ The tribunals' statute merely provided the subject matter jurisdiction; the tribunals relied on custom and general principles for further clarifications. ${ }^{7}$ At the time of the establishment of these tribunals, international criminal law was still developing. So custom and general principles were used in a gap-filling role by these tribunals. ${ }^{8}$ In filling gaps, the tribunal identified criminal law principles that have attained the status of custom, and even went to the extent of formulating the content of international criminal law. ${ }^{9}$ This invited severe criticism because applying the unwritten rule in criminal law amounts to a violation of the principle of legality. ${ }^{10}$ Another reason for criticism was the law-making attitude of tribunals, which goes against international law's basic premise based on states' consent, which is the sine qua non of international law-making. ${ }^{11}$ For example, in the Tadic case, the Appeals Chamber held that the tribunals' jurisdiction is not limited to international armed conflicts; rather, it also extends to non-international armed conflicts. This position of the chamber was in conflict with the plain reading of

POCAR, "Transformation of Customary Law Through ICC Practice" (2018) 112 AJIL Unbound 182; Fausto POCAR, "International Criminal Justice and the Unifying Role of Customary Law" (2016) 21 Uniform Law Review 171; Vladimir-Djuro DEGAN, "On the Sources of International Criminal Law" (2005) 4 Chinese Journal of International Law 45.

${ }^{4}$ Akande, ibid., at 49-50; Pocar, "International Criminal Justice and the Unifying Role of Customary Law", ibid., at 171; Mirjam ŠKRK, "The Notion of Sources of International Criminal Law" in Rüdiger WOLFRUM, Maja SERSIC, and Trpimir Šošić, eds., Contemporary Developments in International Law: Essays in Honour of Budislav Vukas (Leiden/ Boston: Martinus Nijhoff, 2015), 879.

${ }^{5}$ Report of the Secretary-General on UNSC Resolution 808, UNSC Resolution 808, UN Doc. S/25704 (1993), at para. 34 [UNSC]; The Prosecutor v. Duško Tadić, Decision of 15 July 1999, Appeals Chamber, Case No. IT-94-1-A; The Prosecutor v. Anto Furundžija, Decision of 10 December 1998, Trial Chamber, Case No. IT-95-17/1-T.

${ }^{6}$ Comprehensive Report of the Secretary-General on Practical Arrangements for the Effective Functioning of the International Criminal Tribunal for Rwanda, Recommending Arusha as the Seat of the Tribunal, UN Doc. S/1995/134 (1995), at para. 12; this was acknowledged in The Prosecutor v. Jean-Paul Akayesu, Trial Judgment of 2 September 1998, Trial Chamber I, Case No. ICTR-96-4-T at para. 604-7 [Akayesu]; The Prosecutor v. Alfred Musema, Trial Judgment of 27 January 2000, Trial Chamber I, Case No. ICTR-96-13-T at para. 242. The ICTR itself has however indicated that it will be unnecessary and unfair to hold an accused person guilty in relation to conduct that was not clearly defined under international criminal law; The Prosecutor v. Ignace Bagilishema, Appeal Judgment of 3 July 2002, Appeals Chamber, Case No. ICTR-95-1A-a at para. 34.

${ }^{7}$ Guénaël METTRAUX, International Crimes and the ad hoc Tribunals (Oxford: Oxford University Press, 2005).

${ }^{8}$ Art. 38 of ICJ Statute lists international convention, international custom and general principles of law recognized by civilized nations as primary sources, and judicial decisions and the teachings of the most highly qualified publicists of the various nations as subsidiary sources. See Degan, supra note 3 at 46; Mia SWART, "Judicial Lawmaking at the ad hoc Tribunals: The Creative Use of the Sources of International Law and 'Adventurous Interpretation"' (2010) 70 Heidelberg Journal of International Law 459 at 461-2; Daryl A. MUNDIS, "The Legal Character and Status of the Rules of Procedure and Evidence of the ad hoc International Criminal Tribunals" (2001) 1 International Criminal Law Review 191.

${ }^{9}$ Meron, supra note 2 at 817.

${ }^{10}$ Laurence R. HELFER and Anne-Marie SLAUGHTER, "Why States Create International Tribunals: A Response to Professors Posner and Yoo" (2005) 93 California Law Review 899; Dov JACOBS, "International Criminal Law" in Jörg KAMMERHOFER and Jean D'ASPREMONT, eds., International Legal Positivism in a Post-Modern World (Cambridge: Cambridge University Press, 2015), 451 at 458-66.

${ }^{11}$ ALLISON M. Danner, "When Courts Make Law: How the International Criminal Tribunals Recast the Laws of War” (2006) 59 Vanderbilt Law Review 1 at 18. 
the ICTY Statute. ${ }^{12}$ The chamber tried to justify it by arguing that international law has moved away from a state sovereignty centred approach to a human oriented approach. In the same case, the Appeals Chamber held that Article 3 of the ICTY Statute is not limited to Hague Rules only; rather, it includes all international humanitarian law violations other than the four Geneva Conventions' grave breaches. It was held despite the availability of evidence against it in the form of the Secretary-General's report. ${ }^{13}$

To avoid this criticism of violation of the principle of legality, and to formulate the content of international law faced by the ad hoc tribunals, the Rome Statute included a specific provision, Article 21, dealing with applicable law. ${ }^{14}$ It is the first criminal statute that expressly prescribes the law to be applied by the court. ${ }^{15}$ The inclusion of a provision on applicable law is regarded as a "codified moment" in international criminal law. ${ }^{16}$ The inclusion of Article 21 is considered interesting because of its existence, content, and hierarchy. ${ }^{17}$ It requires the ICC to apply the Rome Statute, applicable treaties, principles, and rules of international law, general principles of law derived by the Court from national laws of the legal systems of the world, and its own decision. To further restrict the Court, Article 21 creates a hierarchy among the sources. It uses the words such as "in the first place", "in the second place", and "failing that", which suggest hierarchy within its application. ${ }^{18}$ Such an interpretation requires the Court to give primacy to the Statute. The Court had also agreed to this view in the Al Bashir case when it held that sources mentioned in Article 21(1)(b) and (c) could only be referred to when there are lacunae in the written statute, elements of crime, and rules and such lacunae that cannot be filled by interpreting it in accordance with Article 21(3) of the Rome Statute and Articles 31 and 32 of the Vienna Convention of the Law of Treaties [VCLT]. ${ }^{19}$ In the recent Palestine Judgment, Judge Péter Kovács' Partly Dissenting Opinion has criticized the

\footnotetext{
${ }^{12}$ See The Prosecutor v. Duško Tadić, Decision on the Defence Motion for Interlocutory Appeal on Jurisdiction of 2 October 1995, Appeals Chamber, Case No. IT-94-1-AR72 at para. 97.

${ }^{13}$ William A. SCHABAS, An Introduction to the International Criminal Court, 5th ed. (Cambridge: Cambridge University Press, 2017).

${ }^{14}$ Margaret M. DEGUZMAN, “Article 21, Applicable Law” in Otto TRIFFTERER and Kai AMBOS, eds., The Rome Statute of the International Criminal Court: A Commentary, 3rd ed. (München: C.H. Beck, 2016), 933 at 933, para. 2; Fan, supra note 2 at 1063, 1065.

${ }^{15}$ Gilbert BITTI, "Article 21 and the Hierarchy of Sources of Law before the ICC" in Carsten STAHN, ed., The Law and Practice of the International Criminal Court (Oxford: Oxford University Press, 2015), 411 at 411-12; Gudrun HOCHMAYR, "Applicable Law in Practice and Theory: Interpreting Article 21of the ICC Statute" (2014) 12 Journal of International Criminal Justice 655 at 655-79; Robert CRYER, "Royalism and the King: Article 21 of the Rome Statute and the Politics of Sources" (2009) 12 New Criminal Law Review 390 at 390-405; Leila N. SADAT and Jarrod JOLLY, "Seven Canons of ICC Treaty Interpretation: Making Sense of Article 25's Rorschach Blot" (2014) 27 Leiden Journal of International Law 755 at 755-88.

${ }^{16}$ Joseph POWDERLY, "The Rome Statute and the Attempted Corseting of the Interpretative Judicial Function: Reflections on Sources of Law and Interpretative Technique" in Carsten STAHN, ed., The Law and Practice of the International Criminal Court (Oxford: Oxford University Press, 2015), 444 at 448.

${ }^{17}$ Gilbert BITTI, "Article 21 of the Statute of the International Criminal Court and the Treatment of Sources of Law in the Jurisprudence of the ICC" in Carsten STAHN and Göran SLUITER, eds., The Emerging Practice of the International Criminal Court (Leiden: Martinus Nijhoff, 2009), 281 at 285-6.

${ }^{18}$ Kai AMBOS, "General Principles of Criminal Law in the Rome Statute" (1999) 10 Criminal Law Forum 1 at 1-32; Alessandro BUFALINI, "The Principle of Legality and the Role of Customary International Law in the Interpretation of the ICC Statute" (2015) 14 Law and Practice of International Courts and Tribunals 233 at 233-54.

${ }^{19}$ Decision on the Prosecution's Application for a Warrant of Arrest against Omar Hassan Ahmad Al Bashir (The Prosecutor v. Omar Hassan Ahmad Al Bashir), Decision of 4 March 2009, Pre-Trial Chamber I, Case No. ICC-02/ 05-01/09-3 at para. 44 [Bashir]; Decision on the "Prosecution Request Pursuant to Article 19(3) for a Ruling on the Court's Territorial Jurisdiction in Palestine", Decision of 5 February 2021, Pre-Trial Chamber I, Case No. ICC-01/18 at para 88 [Palestine Judgment].
} 
Court's lacunae-filling approach. He believes that Article 21 does not establish any primacy; rather, it establishes priority. He believes that the Court can restrict itself to sources mentioned in Article 21(1)(a) in simple situations. Still, in complex situations, the Court should not restrict itself from also referring to other sources. ${ }^{20}$ The interpretation relates to using custom as an aid to interpretation. Under Article 21, custom has two roles: first as a source, and second as an aid to interpretation. ${ }^{21}$ The controversy in this paper is restricted to using custom as a source.

Apart from Article 21, there are also other provisions which suggest limited or no application of custom. Article 22(1) provides that "[a] person shall not be criminally responsible under this Statute unless the conduct in question constitutes, at the time it takes place, a crime within the jurisdiction of the Court". The use of the term "crime within the jurisdiction of the Court" restricts the Court from prosecuting those crimes established by custom. ${ }^{22}$ Similarly, Article $25(2)$ provides that a person who commits a crime within the Court's jurisdiction shall be individually responsible and liable for punishment as per this Statute. Even in this provision, the Court is restricted from using the modes of liability mentioned in the Statute and those which go beyond the Statute. ${ }^{23}$ These provisions of the Statute suggest a less significant role of custom within the ICC. ${ }^{24}$

The existing literature is divided on whether custom is part of applicable law under Article 21 or not. Some authors believe that, since international criminal law is part of public international law, and custom is a well-established source, custom should be a source even for international criminal law. ${ }^{25}$ Others believe that, even if there is no explicit reference to custom, the broad formulation of Article 21 would include custom within the ambit of "principles and rules of international law" ${ }^{26}$ While discussing Article 20 of the Draft Statute on Applicable Law, Denmark's representative understood the principles and rules of international law as customary international law. ${ }^{27}$ While discussing the crimes within the Court's jurisdiction, Saudi Arabia's representative said that there was

\footnotetext{
${ }^{20}$ Palestine Judgment, ibid., Partly Dissenting Opinion of Judge Péter Kovács at paras. 97-119.

${ }^{21}$ Yudan TAN, "The Identification of Customary Rules in International Criminal Law" (2018) 34 Utrecht Journal of International and European Law 92.

${ }^{22}$ William A. SCHABAS, The International Criminal Court: A Commentary on the Rome Statute, 2nd ed. (Oxford: Oxford University Press, 2016) at 383-5; Bitti, supra note 17 at 295-6.

${ }^{23}$ Judgment Pursuant to Article 74 of the Statute (The Prosecutor v. Mathieu Ngudjolo Chui), Decision of 18 December 2012, Trial Chamber II, Concurring Opinion of Judge Christine Van den Wyngaert, Case No. ICC-01/04-02/12-4 at para. 9.

${ }^{24}$ Tan, supra note 21; Kai AMBOS, "Remarks on the General Part of International Criminal Law" (2006) 4 Journal of International Criminal Justice 660.

${ }^{25}$ Yeghishe KIRAKOSYAN, "Finding Custom: The ICJ and the International Criminal Courts and Tribunals Compared" in Carsten STAHN and Larissa VAN DEN HERIK, eds., The Diversification and Fragmentation of International Criminal Law (Leiden/Boston: Martinus Nijhoff, 2012), 149 at 154.

${ }^{26}$ Alain PELLET, "Applicable Law” in Antonio CASSESE, Paola GAETA, and John R.W.D. JONES, eds., The Rome Statute of the International Criminal Court: A Commentary (Oxford: Oxford University Press, 2002), 1051; J. VERHOEVEN, "Article 21 of the Rome Statute and the Ambiguities of Applicable Law" (2002) 33 Netherlands Yearbook of International Law 2; Larissa VAN DEN HERIK, "The Decline of Customary International Law as a Source of International Criminal Law" in Curtis A. BRADLEY, ed., Custom's Future: International Law in a Changing World (Cambridge: Cambridge University Press, 2016), 230; William A. SCHABAS, The International Criminal Court: A Commentary on the Rome Statute (Oxford: Oxford University Press, 2010) at 396; Otto TRIFFTERER, "Preliminary Remarks: The Permanent International Criminal Court-Ideal and Reality" in Otto TRIFFTERER and Kai AMBOS, eds., The Rome Statute of the International Criminal Court: A Commentary, 3rd ed. (München: C.H. Beck, 2016), at 128; Ian BROWNLIE, Principles of Public International Law, 7th ed. (Cambridge: Cambridge University Press, 2008) at 19; Bitti, supra note 17 at 295-6; Akande, supra note 3 at 51.

${ }^{27}$ Report of the Preparatory Committee on the Establishment of an International Criminal Court, UN Diplomatic Conference of Plenipotentiaries on the Establishment of an International Criminal Court (Rome 15 June-17 July 1998) (23 June 1998), UN Doc. A/CONF.183/C.1/L.53 at 224.
} 
no such general international law, so the term should be replaced by customary international law. ${ }^{28}$ There is hardly any jurisprudence developed by the ICC which has expressly referred to custom as a source. The main reason for the exclusion of custom is the influence exercised by criminal lawyers. These lawyers believe that if custom is expressly included it will violate the principle of legality. ${ }^{29}$ So the question arises as to whether the use of the words "principles and rules of international law" includes custom. This paper will engage with the reasoning behind reading custom within "principles and rules of international law", and whether such a reading would be contrary to the structure of Article 21 and the principle of legality.

Despite the opposing views among authors regarding the inclusion of custom within Article 21, custom has an important role in international criminal law jurisprudence. Before the ICC, custom played an important role in cases before the ad hoc tribunals. For example, the Appeals Chamber in the Tadic case established the customary status of criminalizing serious violations in non-international armed conflict as war crimes. The decision came even though there was no support for it either in the Geneva Convention or in the Additional Protocol. This position gained strength by the subsequent decision of the ICTY. The ICTR has also used custom in the cases before it. In the Akayesu case, it confirmed the customary status of the Genocide Convention. ${ }^{30}$ Subsequently, the tribunals in several cases have used custom as a source in cases before them. ${ }^{31}$ Even though tribunals have faced criticism for formulating customary law as per their need, the jurisprudence developed by it has helped in the development of international criminal law. ${ }^{32}$

Under the Rome Statute, the inclusion of Article 21 has raised several questions as to whether custom is a source under the ICC. Supposing it to be a source, how can it then be applied, bearing in mind the hierarchy established by Article 21 and the lacunae-filling role assigned to it by the court in Al Bashir's case $?^{33}$ This paper will look into whether custom can be considered a source under Article 21 of the Rome Statute. The paper then highlights certain instances provided by the Statute itself, which gives scope for applying the custom.

\section{Custom as part of Article 2I of the Rome Statute}

There are two arguments for reading custom under Article 21. The first one is that international criminal law is part of public international law; hence, the ICC can use the sources mentioned under Article 38 of the ICJ Statute. ${ }^{34}$ Article 38 lists custom as a source along with treaties as general principles of law. Even though the provision is aimed at application by the ICJ, it has been used in the discussion by other bodies, including ad hoc tribunals. ${ }^{35}$ However, the difference between the ad hoc tribunal and the ICC is

\footnotetext{
${ }^{28}$ Ibid.

${ }^{29}$ Pellet, supra note 26 at 1070-1; deGuzman, supra note 14 at 938-9; Christopher L. BLAKESLEY, "Comparing the Ad Hoc Tribunal for Crimes Against Humanitarian Law in the Former Yugoslavia and the Project for an International Criminal Court, Prepared by the International Law Commission" (1996) 67 International Review of Penal Law 139 at 146; M. Cherif BASSIOUNI and Christopher L. BLAKESLEY, "The Need for an International Criminal Court in the New International World Order" (1992) 25 Vanderbilt Journal of Transnational Law 151 at $175-6$.

${ }^{30}$ Akayesu, supra note 6 at para. 495.

${ }^{31}$ See Decision on Motions for Acquittal Pursuant to Rule 98 bis of the Rules of Procedure and Evidence (The Prosecutor v. Hadžihasanović and Kubura), Decision of 27 September 2004, Trial Chamber, Case No. IT-01-47-T.

${ }^{32}$ Allison, supra note 11.

${ }^{33}$ Bashir, supra note 19 at para. 44.

${ }^{34}$ Akande, supra note 3 at 45.

${ }^{35}$ Robert Y. JENNINGS, "What is International Law and How Do We Tell It When We See It?" in Martti KOSKENNIEMI, ed., Sources of International Law (London: Routledge, 2000), 27; Robert Y. JENNINGS, "The
} 
that the Rome Statute contains a specific provision dealing with applicable law. The availability of a provision on applicable law means that the Court will restrict itself to the Statute's mandate. This is evident from the wording "in the first place" used in Article 21, which means that the Court will first apply the statute, and that it will prevail over other sources. ${ }^{36}$

The second argument is that the term used under Article 21(1)(b) is "principles and rules of international law", which is a broad terminology that might also include custom. ${ }^{37}$ Custom and general principles are sources of international law as per Article 38 of the ICJ Statute. The difference between Articles 38 and 21 is that the former expressly mentions custom and general principles as a separate source, but the latter does not expressly include custom. Article 21, however, makes a difference between general principles of the law specific to international law and general principles of law derived from national laws. Akehurst believed that international law's general principles are broader principles of international law, including custom and general principles of law. ${ }^{38}$ Since Article 21(1)(c) expressly recognizes the general principle of law derived from national law, the only possibility that remains is that it implies custom. ${ }^{39}$ The Special Rapporteur's first and second report on general principles also recognizes these two categories of general principles of law. ${ }^{40} \mathrm{He}$ has also clarified that the term "general principles of international law" or "principles of international law" must be analyzed carefully because in some cases it might be used to refer to the general principles of law formed within the international legal system, or in some cases it might be referring to conventional rules, customary international law, or even general principles of law derived from the national legal system. ${ }^{41}$

The reason for using the words "principles" and "rules" is that, in criminal law, the crime is generally committed under government participation or by their tacit approval, so it would be difficult for national courts to prosecute them. Such a nature of international crime makes it hard to detect state practice required for customary law. ${ }^{42}$ To avoid this difficulty, the State Parties may have used the term "principles and rules of international law". But, on the other hand, there is also a view that the modern approach of finding custom through the deductive process pays more attention to the general

Judiciary, International and National, and the Development of International Law" (1996) 45 International Comparative Law Quarterly 1; Robert CRYER, "Neither Here Nor There? The Status of International Criminal Jurisprudence in the International and UK Legal Orders" in K.H. KAIKOBAD and M. BOHLANDER, eds., International Law and Power: Perspectives on Legal Order and Justice (Leiden/Boston: Martinus Nijhoff, 2009), 183.

${ }^{36}$ Akande, supra note 3 at 45.

37 deGuzman, supra note 14 at 942; Mohamed BENNOUNA, "The Statute's Rules on Crimes and Existing or Developing International Law" in Antonio CASSESE, Paola GAETA, and John R.W.D. JONES, eds., The Rome Statute of the International Criminal Court: A Commentary, vol. II (Oxford: Oxford University Press, 2002), 1101 at 1105; Pellet, supra note 26 argues that customary international law may even be considered beyond the scope of the definitions of international crimes set out in the ICC Statute; Brownlie, supra note 26 at 19; Holger HESTERMEYER, "Access to Medication as a Human Right" (2004) 8 Max Planck Yearbook of United Nations Law 101 at 158.

${ }^{38}$ Michael AKEHURST, “The Hierarchy of the Sources of International Law” (1975) 47 British Yearbook of International Law 273 at 279.

${ }^{39}$ Hochmayr, supra note 15 at 668.

${ }^{40}$ First Report on General Principles of Law (ILC), Report by the Special Rapporteur Marcelo VÁZQUEZ-BERMÚDEZ, UN Doc. A/CN.4/732 (2019), Draft Conclusion 3, at 75.

${ }^{41}$ Second Report on General Principles of Law (ILC), Report by the Special Rapporteur Marcelo VÁZQUEZ-BERMÚDEZ, UN Doc. A/CN.4/741 (2020), at 38, paras. 118-19.

${ }^{42}$ Roozbeh (Rudy) B. BAKER, "Customary International Law in the 21st Century: Old Challenges and New Debates” (2010) 21 European Journal of International Law 173 at 173-204. 
statement of rules and abandons the state practice requirement. ${ }^{43}$ The distinction between custom and general principles will become "artificial" or even "illusory" if opinio juris is given more importance than state practice. ${ }^{44}$

However, the merging of custom and general principles raises specific problems. ${ }^{45}$ First, it would be challenging to reconcile it with Article 38 of the ICJ Statute and Article 21 of the Rome Statute. Both these provisions recognize general principles of law as a separate source, so the merger would mean that Article 38(1)(c) and Article 21 (1)(c) are of no use. Second, the merger might hamper the universal acceptance of both these provisions. The view of reading both these sources together has emerged from a common-law viewpoint. Lord Phillimore, the UK member of the Advisory Committee of Jurists for the Establishment of a Permanent Court of International Justice, argued that general principles came within the scope of customary law. ${ }^{46}$ According to this view, custom is the product of legal or moral beliefs or judicial lawmaking, and not state practice and opinio juris. ${ }^{47}$ Third, the Court's practice, especially the ICJ, is not consistent with the unitary view of reading custom and general principles together. The Court has referred to "principles" or "general principles" in several cases without clarifying their status. ${ }^{48}$ This view justifies the practice of the ICJ in adopting the two-element approach in identifying custom. Whenever state practice has fallen short, it has referred to it as a general principle or principle. ${ }^{49}$

Another reason for not reading custom as a source under Article 21 is that the word "general" is deleted from the State Parties' final Statute. The 1994 draft included "general", which has been understood to include customary international law. ${ }^{50}$ There is a difference between general and particular norms. Since customary international law binds all states it is a general law; a particular treaty or convention binds only those states

\footnotetext{
${ }^{43}$ Anthea ROBERTS, "Traditional and Modern Approaches to Customary International Law: A Reconciliation" (2001) 95 Asian Journal of International Law 757 at 758; Stefan TALMON, "Determining Customary International Law: The ICJ's Methodology between Induction, Deduction and Assertion” (2015) 26 European Journal of International Law 417.

${ }^{44}$ Brian D. LEPARD, Customary International Law: A New Theory with Practical Applications (Cambridge: Cambridge University Press, 2010) at 163; B.S. CHIMNI, “Customary International Law: A Third World Perspective” (2018) 112 Asian Journal of International Law 1; P.S. RAO, "The Identification of Customary International Law: A Process that Defies Prescription" (2017) 57 Indian Journal of International Law 221.

${ }^{45}$ Thomas KLEINLEIN, "Customary International Law and General Principles" in Brian D. LEPARD, ed., Reexamining Historical and Theoretical Perspectives on Customary International Law (Cambridge: Cambridge University Press, 2017), 131 at 146-7.

${ }^{46}$ League of Nations, "Procès-Verbaux of the Proceedings of the Committee, 16th June-24th July, 1920" (7 November 2007), online: Internet Archive <https://archive.org/details/procsverbauxofooleaguoft/page/i> at 295, 311, 316; Humphrey WALDOCK, “General Course on Public International Law" (1962) 106 Recueil des cours de I'Academie de Droit International 39 (stating that international custom and general principles are the "common law" of the international community).

${ }^{47}$ Hilary CHARLESWORTH, "Law-Making and Sources" in James CRAWFORD and Martti KOSKENNIEMI, eds., The Cambridge Companion to International Law (Cambridge: Cambridge University Press, 2012), 187 at 192.

${ }^{48}$ Alain PELLET, "Article 38" in Andreas ZIMMERMANN, Christian TOMUSCHAT, and Karin OELLERS-FRAHM, eds., The Statute of the International Court of Justice: A Commentary (Oxford: Oxford University Press, 2006), 677 at 766.

${ }^{49}$ Giorgio GAJA, “General Principles of Law” in Rüdiger WOLFRUM, ed., Max Planck Encyclopedia of Public International Law, vol. IV (Oxford: Oxford University Press, 2012), 370 at 374, para. 18; Jan WOUTERS and Cedric RYNGAERT, "Impact on the Process of the Formation of Customary International Law" in Menno T. KAMMINGA and Martin SCHEININ, eds., The Impact of Human Rights Law on General International Law (Oxford: Oxford University Press, 2009), 111.

${ }^{50}$ Grigory TUNKIN, “Is General International Law Customary Only?” (1993) 4 European Journal of International Law 534 at 534-5; Brownlie, supra note 26 at 19.
} 
which have signed that particular treaty. ${ }^{51}$ Conventional norms will only become customary law if supported by sufficient opinio juris, because membership of a particular treaty merely shows state practice. ${ }^{52}$

\section{The object of Article 2 I and custom}

Custom has not been included expressly in the Rome Statute because states were aware of the criticism levelled against the ad hoc tribunals. The ICC is a rule-based regime where the rules and standards are publicly declared in advance by the competent authority. This reasoning suggests that formulating and using custom within criminal law would violate the principle of legality. ${ }^{53}$ The object of introducing Article 21 was strict adherence to the principle of legality and to limit the power of judges to formulate the content of international law and use custom as and when needed. ${ }^{54}$ If the ICC applies custom in ways in which the ad hoc tribunals have applied it, it will frustrate the very object for which a provision on applicable law was introduced. ${ }^{55}$

The principle of legality is included in Articles 22, 23, and 24 of the Rome Statute. It requires that prosecution and punishment be based upon the explicit provision of law in force when the crime was committed. The act which constitutes a crime must be "within the jurisdiction of the court". The consequence of using the phrase "within the jurisdiction of the court" is to exclude any possibility of prosecution for offences based solely on customary law. ${ }^{56}$ The principle also requires that crimes within the Court's jurisdiction are defined with clarity, precision, and specificity. ${ }^{57}$ Pre-Trial Chamber I in the Lubanga Dyilo case observed that there would be no violation of the principle of legality:

... if the Chamber exercises its power to decide whether Thomas Lubanga Dyilo ought to be committed for trial based on written (lex scripta), pre-existing criminal norms approved by the States Parties to the Rome Statute (lex praevia), defining prohibited conduct and setting out the related sentence (lex certa), which cannot be interpreted by analogy in malam partem (lex stricta). ${ }^{58}$

The rule on specificity and certainty requires the definition of crime to be clear and precise. The rule on non-retroactivity prohibits prosecution for offences which were not declared by law to be an offence when the particular act was committed. The rule of the ban on analogy has been included in Article 22(2), which requires the Court to

\footnotetext{
${ }^{51}$ Military and Paramilitary Activities in and against Nicaragua (Nicaragua v. United States of America), Decision of 27 June 1986 (Merits), [1986] I.C.J. Rep 14 at para. 183.

${ }^{52}$ See Maarten BOS, A Methodology of International Law (Amsterdam: North Holland, 1984) at 67.

${ }^{53}$ George P. FLETCHER and Jens David OHLIN, "Reclaiming Fundamental Principles of Criminal Law in the Darfur Case" (2005) 3 Journal of International Criminal Justice 539 at 559; for discussions about the principle of legality, see Mohamed SHAHABUDDEEN, "Does the Principle of Legality Stand in the Way of Progressive Development of Law?" (2004) 2 Journal of International Criminal Justice 1007; Shahram DANA, "Beyond Retroactivity to Realizing Justice: A Theory on the Principle of Legality in International Criminal Law Sentencing" (2009) 99 Journal of Criminal Law and Criminology 857; Kirakosyan, supra note 25 at 149; Shane DARCY, Judges, Law and War: The Judicial Development of International Humanitarian Law (Cambridge: Cambridge University Press, 2014) at 62.

${ }^{54}$ David HUNT, “The International Criminal Court: High Hopes, ‘Creative Ambiguity' and an Unfortunate Mistrust in International Judges” (2004) 2 Journal of International Criminal Justice 56.

${ }^{55}$ Powderly, supra note 16 at 444.

${ }^{56}$ Schabas, supra note 13 at 407.

${ }^{57}$ Bruce BROOMHALL, "Article 51" in Otto TRIFFTERER, ed., Commentary on the Rome Statute of the International Criminal Court, 2nd ed. (Oxford: Hart, 2008), 1033 at 1044.

${ }^{58}$ Decision on the Confirmation of Charges (The Prosecutor v. Thomas Lubanga Dyilo), Decision of 7 February 2007, Pre-Trial Chamber I, Case No. ICC-01/04-01/06 at para. 303 [Dyilo].
} 
construe the meaning of a crime strictly. In the case of ambiguity, the interpretation must be made in favour of the accused. Such a requirement by the Court focuses on the importance of determinacy in criminal law.

To comply with the principle of legality, ad hoc tribunals, especially the ICTY, were asked to apply those rules which are "beyond any doubt part of customary law". ${ }^{59}$ Since the criminal law was still developing at the international level, ad hoc tribunals' statute had a lot of gaps. In filling those gaps, the tribunal went to the extent of formulating the content of international law. ${ }^{60}$ The reason for such criticism was the nature of custom and its method of formation. ${ }^{61}$ The principle of legality requires that the law must be written and known to the public in advance. Still, in the case of customary law, it is unwritten, and it is generally founded by the court when any situation requires it. It also gives judges a lot of discretion to ascertain the content of a particular customary law. ${ }^{62}$ The uncertainty and imprecise legal content of custom goes against foreseeability and determinacy as required by the principle of legality. The flexibility and changing nature of the constitutive elements of custom (state practice and opinio juris) influence legal certainty. ${ }^{63}$ The nature of this has not changed with the enactment of the Rome Statute; this criticism would apply to the ICC's customary law application.

\section{The possibility of the application of custom under the Rome Statute}

As discussed in the previous section, the inclusion of custom within Article 21 appears debatable. However, the formulation of the Statute leaves scope for the application of custom. However, the application of custom is subject to the fulfilment of two conditions as laid down by the Pre-Trial Chamber in the Al Bashir case. It laid down that customary rules and general principles of law:

can only be applied when the following two conditions are met: (i) there is a lacuna in the written law contained in the Statute, the Elements of Crimes and the Rules; and (ii) such lacuna cannot be filled by the application of the criteria provided for in articles 31 and 32 of the Vienna Convention on the Law of the Treaties and article 21(3) of the Statute. ${ }^{64}$

Such a requirement is needed because of the words "in the second place" in Article 21 of the Statute, implying a subsidiary role to sources other than the Statute itself. The direct application of custom by the ICC has been limited by the hierarchy established by Article 21 and the lacunaefilling role provided to it by the Al Bashir case. There are certain instances in the Statute which probably would require the application of customary law. Those instances are given below.

\section{A. Definition of war crime (Article 8)}

Article 8 defines war crime, and elements of the crime have further elaborated it. The elements of crime suggest that war crime shall be interpreted within the established

\footnotetext{
${ }^{59}$ UNSC, supra note 5 at para. 34.

${ }^{60}$ Degan, supra note 3 at 68-9; Anthony A. D'AMATO, The Concept of Custom in International Law (Ithaca \& London: Cornell University Press, 1971); Noora ARAJÄRVI, The Changing Nature of Customary International Law: Methods of Interpreting the Concept of Custom in International Criminal Tribunals (London \& New York: Routledge, 2014). This issue has been recently dealt with by the Special Rapporteur of the International Law Commission on the Identification of International Customary Law, who significantly called for a unified approach: Second Report on Identification of Customary International Law, Report by the Special Rapporteur Michael WOOD, UN Doc. A/CN.4/672 (2014), at 12.

${ }^{61}$ Fletcher and Ohlin, supra note 53.

${ }^{62}$ Hunt, supra note 54.

${ }^{63}$ Ibid.

${ }^{64}$ Bashir, supra note 19 at 44.
} 
framework of international humanitarian law. Even Article 21(b) directs the Court to apply general principles of international law, including the established principles of the international law of armed conflict. Some aspects of war crime have been declared as customary international law. ${ }^{65}$ The Rome Statute refers to international armed conflict and non-international armed conflict, but the Statute has not adopted the definition of these terms. In the earliest cases before it, the Court has to deal with this definition; then, it recognized that the Statute does not define these terms. ${ }^{66}$ The Trial Chamber then relied on the definition laid down by the ICTY in the Tadic case because it reflects the customary law. ${ }^{67}$ The court in the Bemba Gombo Decision relied on the already established definition of civilian and non-civilian populations. ${ }^{68}$

Within the definition of war crimes, there are provisions (Article 8(2)(b) and Article 8 (2)(e)) which use the term "other serious violations of the laws and customs applicable in international or non-international armed conflict, within the established framework of international law". This term is an amalgamation of the older notion of "laws and custom of war" and modern international humanitarian law. Laws and custom of war were used to refer to customary law, so that even within the ambit of Article 8 the Court can rely upon those principles of humanitarian law which have attained the status of customary law. ${ }^{69}$ Even the ICC in this direct reference in the Statute itself implies that the Court can directly apply custom.

\section{B. Retroacctive application of the Court's jurisdiction (Articles I2 and I3)}

There are two situations under the Statute in which the Court exercises its jurisdiction retrospectively. ${ }^{70}$ Article $12(3)$ deals with a situation in which a state, whether a party to the Statute or not, grants the Court jurisdiction over a situation that has taken place when the state has not accepted the application of the Rome Statute. For example, Ukraine submitted its declaration in 2014 and 2015, but had accepted the Court's jurisdiction since $2013 .^{71}$ In the case of Palestine, the declaration was submitted in January 2015, accepting the Court's jurisdiction over crimes since $2014 .{ }^{72}$ Similarly, Côte d'Ivoire accepted the jurisdiction of the Court in 2003 over the acts committed in 2002. Later on, Côte d'Ivoire went on to ratify the Rome Statute in $2013 .^{73}$ The second situation deals with Security Council referral under Article 13(b). In the case of Security Council referrals, the situation

\footnotetext{
${ }^{65}$ Christopher GREENWOOD, "The Development of International Humanitarian Law by the International Criminal Tribunal for the Former Yugoslavia" (1998) 2 Max Planck Yearbook of United Nations Law at 97; Theodor MERON, "The Hague Tribunal: Working to Clarify International Humanitarian Law" (1998) 13 American University International Law Review at 1511.

${ }^{66}$ Dyilo, supra note 58 at paras. 208-9.

${ }^{67}$ Judgment Pursuant to Article 74 of the Statute (The Prosecutor v. Thomas Lubanga Dyilo), Decision of 5 April 2012, Trial Chamber I, Case No. ICC-01/04-01/06-2842 at para. 533 [Dyilo].

${ }^{68}$ Decision Pursuant to Article 61(7)(a) and (b) of the Rome Statute on the Charges of the Prosecutor Against Jean-Pierre Bemba Gombo (The Prosecutor v. Jean-Pierre Bemba Gombo), Decision of 15 June 2009, Pre-Trial Chamber II, Case No. ICC-01/05-01/08-424 at para. 78 (see footnote 101) [Gombo].

${ }^{69}$ Knut DÖRMANN, “Article 8” in Otto TRIFFTERER and Kai AMBOS, eds., The Rome Statute of the International Criminal Court: A Commentary, 3rd ed. (München: C.H. Beck, 2016), 354 at para. 180.

${ }^{70}$ Antonio CASSESE, "When May Senior State Officials Be Tried for International Crimes? Some Comments on the Congo v. Belgium Case" (2002) 13 European Journal of International Law 853 at 875; Marko MILANOVIC, "Is the Rome Statute Binding on Individuals? (And Why We Should Care)" (2011) 9 Journal of International Criminal Justice 25 at 25, 51-2; Marko MILANOVIC, "Aggression and Legality: Custom in Kampala" (2012) 10 Journal of International Criminal Justice 165.

${ }^{71}$ Declaration by Ukraine lodged under art. 12(3) of the Rome Statute (9 April 2014); Declaration by Ukraine lodged under art. 12(3) of the Rome Statute (8 September 2015).

72 Declaration by Palestine lodged under art. 12(3) of the Rome Statute (31 December 2014).

${ }^{73}$ Declaration by Côte d'Ivoire lodged under art. 12(3) of the Rome Statute (18 April 2003).
} 
referred to relates to a state that is not a party to it and not subject to the Court's jurisdiction when the act in question took place, for example the situation referred by the United Nations Security Council in Darfur and Libya. ${ }^{74}$ One of the requirements of the principle of legality is the non-retroactive application of the Court's jurisdiction. ${ }^{75}$ It means that the law that has criminalized the conduct must apply to the accused when it was committed. Apart from applicability, the principle of legality also requires that the law must be accessible and foreseeable to the individual. ${ }^{76}$ The application of jurisdiction in these two cases can be justified because the conduct in question has already been prohibited through prior existing customary international law. ${ }^{77}$ Even though there is the possibility to use custom as a source to justify the exercise of jurisdiction, the Court has not used it.

\section{Mental element (Article 30)}

Article 30 refers to the mental element needed to commit a particular crime. It relates only to intent and knowledge as mental elements. There is a possibility of the existence of other mental elements like recklessness and dolus eventualis. The provision begins with the term "unless otherwise provided", which suggests that Article 30 is the default rule in all mental elements, and that there may be deviations where otherwise provided. ${ }^{78}$ It has been argued that this term refers to existing customary law, implying that there is a possibility of including any mental element established in customary law even though it has not been mentioned in the Statute. ${ }^{79}$ If such understanding exists, it will contradict the hierarchy established by Article 21, which requires the Statute to be given primacy over the other sources. Article 30 would no more be the default rule. It also means that the lower standard mentioned in customary law would be applied instead of the standard in Article 30, which would ultimately violate the principle of legality because criminal law requires that interpretation to be accepted which is in favour of the accused. $^{80}$ Through its decision in Bemba Gombo, the ICC has maintained the hierarchy by observing that "Article 30 has to be applied unless the Rome Statute or the Elements of Crimes require a different standard of fault". ${ }^{81}$

There are certain crimes which require a mental element other than intent and knowledge. Some of the provisions in war crimes (Article 8(2)(a)(i) and (iii)) mention "wilful" and "wilfully", and the definition of genocide uses "deliberately" (Article 6(c)). The

\footnotetext{
${ }^{74}$ United Nations Security Council, UNSC Res. 1593, UN Doc. S/RES/1593 (31 March 2005); United Nations Security Council, UNSC Res. 1970, UN Doc. S/RES/1970 (26 February 2011).

${ }^{75}$ M. Cherif BASSIOUNI, "Principles of Legality in International and Comparative Criminal Law" in M.C. BASSIOUNI, ed., International Criminal Law: Sources, Subjects and Contents (Leiden: Brill/Nijhoff, 2008), 73 at 89; B.V. SCHAACK, "Crimen Sine Lege: Judicial Lawmaking at the Intersection of Law and Morals" (2008) 97 Georgetown Law Journal 119 at 158-72.

${ }^{76}$ Kenneth GALLANT, The Principle of Legality in International and Comparative Criminal Law (Cambridge: Cambridge University Press, 2010) at 20.

${ }^{77}$ For more on the solution to the issue of retroactivity, see Talita DESOUZA DIAS, "The Retroactive Application of the Rome Statute in Cases of Security Council Referrals and Ad Hoc Declarations: An Appraisal of the Existing Solutions to an Under-Discussed Problem" (2018) 16 Journal of International Criminal Justice 65; Bruce BROOMHALL, "Article 22" in Otto TRIFFTERER, ed., Commentary on the Rome Statute of the International Criminal Court, 2nd ed. (Oxford: Hart, 2008), 713 at 713, 720.

${ }^{78}$ Donald K. PIGAROFF and Darryl ROBINSON, “Article 30" in Otto TRIFFTERER and Kai AMBOS, eds., The Rome Statute of the International Criminal Court: A Commentary, 3rd ed. (München: C.H. Beck, 2016), 1112 at 1118.

${ }^{79}$ Gerhard WERLE and Florian JESSBERGER, “'Unless Otherwise Provided': Article 30 of the ICC Statute and the Mental Element of Crimes under International Criminal Law" (2005) 3 Journal of International Criminal Justice 35; Steffen WIRTH, "Co-Perpetration in the Lubanga Trial Judgment" (2012) 10 Journal of International Criminal Justice 971.

${ }^{80}$ Bufalini, supra note 18 at $244-5$.

${ }^{81}$ Gombo, supra note 68 at paras. $163,353-4$.
} 
uses of these terms have been reproduced from the definition of war crime and genocide, and these definitions have attained the status of customary law. ${ }^{82}$ Such a reference gives further scope for the application of custom.

\section{Grounds for excluding criminal responsibility (Article 3I)}

Article 31 provides grounds for excluding criminal responsibility. It lists incapacity, intoxication, self-defence, defence of another person, and defence of property in war crimes, and duress as grounds for excluding responsibility. Article 31(3) provides that, apart from these grounds, the Court may apply any other ground provided that the ground is derived from applicable law as laid down in Article 21, which is argued to also include customary law. ${ }^{83}$ However, in this, it is the Statute itself which refers to the application of customary law. In this case, there are no lacunae that need to be filled. Article 31 does not include an exhaustive list of defences because defences on military necessity or reprisal are not mentioned. ${ }^{84}$ These grounds have been established to be a ground for defence within criminal law. ${ }^{85}$ When this provision came for discussion before the State Parties, the state's representatives were worried about giving a lot of discretion to the Court's judges. ${ }^{86}$ Such a formulation of the provision is considered as a trade-off between the need to repress these crimes and the fundamental rights available to the accused before criminal courts. ${ }^{87}$

These circumstances suggest that there is still a role for customary international law within the Rome Statute. With the codification of criminal law, the Court has used it very rarely. There is a need for the ICC to develop a consistent practice to find lacunae and then fill them with the help of custom. Apart from lacunae, as per Article 21, the Court will also have to look at whether it would be "appropriate" to apply a particular customary law. The appropriateness has to be determined by looking at the norm which is to be used and the context in which it is to be applied. ${ }^{88}$ In the case against Thomas Lubanga Dyilo, the Trial Chamber held that the procedure of witness preparation before trial is not easily transferable into the system of law created by the ICC Statute and Rule. The Court reached this conclusion by assessing whether this procedure would fit into the system designed by the Statute or not. If it does not fit within it, it would not be appropriate to apply any principles and rules. ${ }^{89}$

\section{Conclusion}

Custom played a significant role in the development of international criminal law. Before the ICC, the ad hoc tribunals used and formulated custom because there were a lot of gaps

\footnotetext{
${ }^{82}$ Pigaroff and Robinson, supra note 78 at 1120.

${ }^{83}$ Kai AMBOS, Treatise on International Criminal Law, vol. I: Foundations and General Part (Oxford: Oxford University Press, 2013) at 386; Elies VAN SLIEDREGT, Individual Criminal Responsibility in International Law (Oxford: Oxford University Press, 2012) at 223.

${ }^{84}$ Kai AMBOS, "Defences in International Criminal Law" in B.S. BROWN, ed., Research Handbook on International Criminal Law (Cheltenham: Edward Elgar, 2011), 299 at 299.

${ }^{85}$ Gerhard WERLE and Florian JEßBERGER, eds., Principles of International Criminal Law (Oxford: Oxford University Press, 2009) at para. 539.

${ }^{86}$ Preparatory Committee on the Establishment of an International Criminal Court, Volume 1: Proceedings of the Preparatory Committee during March-April and August 1996, UN GA Official Records 51st Sess. Supp. No. 22A (A/51/22) (1996), at para. 204.

${ }^{87}$ Ambos, supra note 18 at 28.

${ }^{88}$ Bufalini, supra note 18 at 239.

${ }^{89}$ Decision Regarding the Practices Used to Prepare and Familiarise Witnesses for Giving Testimony at Trial (The Prosecutor v. Thomas Lubanga Dyilo), Decision of 1 December 2007, Trial Chamber I, Case No. ICC-01/04-01/ 06-1049 at para. 45.
} 
in the statutes. The tribunals were criticized for formulating the custom and content of international law as per their need. Such practice goes against the principle of legality. The drafters were aware of the criticisms, so they included Article 21, a specific provision on applicable law. In place of custom, they have used the term "principles and rules of international law", which may imply those principles specific to international law or even customary law. The practice of the Court has not expressly referred to custom as a source. It has referred to and used those principles, which have become part of custom. ${ }^{90}$ The main reason for not expressly mentioning it could be the requirements of the principle of legality. The nature and method of formulation of custom stand in contrast to the principle of legality. However, despite the careful drafting, the Statute provides enough scope to use custom as a source in any situation before it.

With regard to the lacunae-filling approach assigned to custom and other sources, the question arises as to whether applying these sources to fill those lacunae will violate the principle of legality or not. The Court needs to clarify what "lacunae" means because cases like the definition of war crimes which directly refer to the international law of armed conflict can be considered as lacunae or not. Whether the use of custom in the circumstances, for example, Article 31, in which the provision allows for the use of custom, will violate the hierarchy and principle of legality. Another question that arises is that the lacunae filled by using custom as a source will be in accordance with the hierarchy established under this provision. The Court's judgments may clarify the confusion as to whether custom is a source under Article 21 or not and the situations in which it can be applied.

${ }^{90}$ Dyilo, supra note 67 at para. 533; Gombo, supra note 68 at para. 78 (see $\mathrm{ftn} 101$ ).

Cite this article: KUMAR A (2021). Custom as a Source Under Article 21 of the Rome Statute. Asian Journal of International Law 11, 232-244. https://doi.org/10.1017/S2044251321000205 